\title{
Druckfehler und Berichtigungen
}

für den XXXVI. Band der Monatshefte für Chemie (1915)

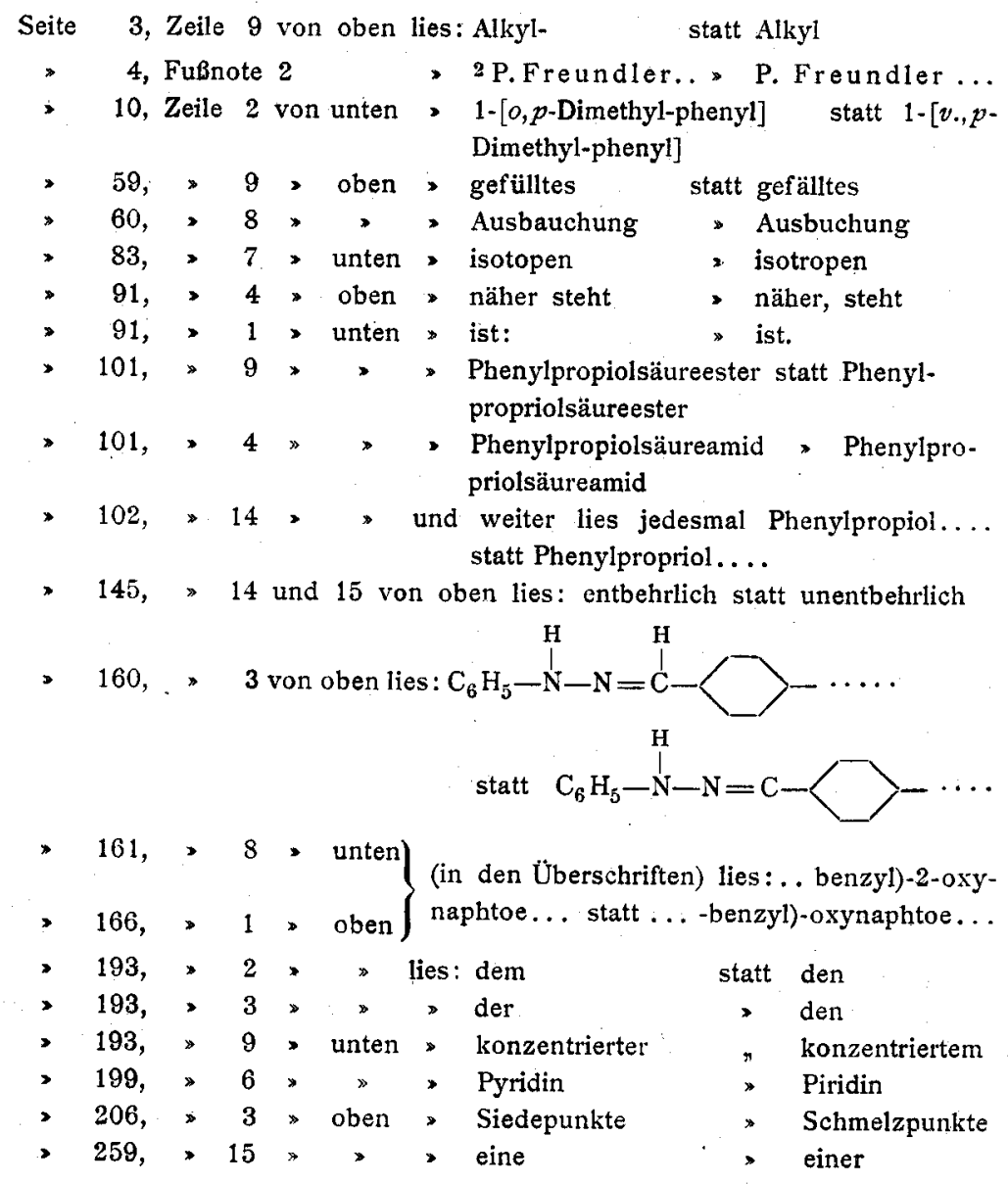




\section{VIII}

Seite 318 , Zeile 2 von unten lies: röhren

statt löhren

\362, $>6$ oben $\gg$ die

$\triangleright$ dle

> 529, $>3$ > Acetylsemicarbazid * Azetylsemi-

carbazid

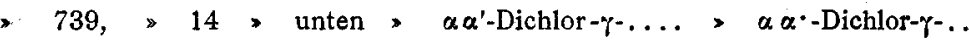

-924, 13 > in der Tabelle, Spalte 2 von rechts lies:

$114 \cdot 5$

statt $134 \cdot 5$

$\gg 929, \rightarrow 7 \rightarrow$ oben lies: 29. April

28. April 